\title{
Multi-agency approaches in 'criminogenic' settings: the case of the Amsterdam Red Light District
}

\author{
Edward R. Kleemans ${ }^{1}$ • Wim Huisman ${ }^{1}$
}

Published online: 24 October 2015

C The Author(s) 2015. This article is published with open access at Springerlink.com

\begin{abstract}
This paper assesses the empirical evidence on multi-agency collaboration to reduce crime, uphold justice and improve safety in the so-called 'Red Light District' in the city center of Amsterdam, which has been a high crime area for decades. Three periods are analyzed: crime on the streets (1980s-1996); organized crime behind the front doors (1996-2007); and reconquering the Red Light District (2007-2011). The paper analyzes shifts in the definition and framing of central crime problems, causal assumptions, policy assumptions, and evidence on multi-agency collaboration and outcomes. Alongside positive outcomes, all three periods contain evidence on how difficult it is to forge and sustain alliances between government agencies; and to coordinate a shared focus on a single area and on a single topic. Furthermore, the final outcomes of these efforts are hard to measure with the exception of visible street crime. Finally, the paper contributes to the literature on Third Party Policing and multi-agency collaboration by looking beyond the police as the central actor and by widening the predominant instrumental focus to normative and political issues such as changing norms, priorities, and increasing and decreasing internal and external support for certain policy lines and actions.
\end{abstract}

\section{Introduction}

Attempts to reduce crime, uphold justice and improve safety in modern cities are embedded within a wider social and political context. In the realm of policy making, 'rational' answers to problems are only one part of the story. Policies change and react to shifting constellations of problem definitions, contemplated solutions, and political support (e.g., [1]). Sometimes 'policy windows' emerge for a different approach to crime problems, but these different approaches may also be subject to the tide of rising and waning political support, outside and inside collaborating agencies (e.g., [2]).

Edward R. Kleemans

e.r.kleemans@vu.nl

1 VU School of Criminology, Department of Criminal Law and Criminology, Faculty of Law, VU University Amsterdam, De Boelelaan 1105, 1081 HV Amsterdam, The Netherlands 
The so-called 'Red Light District' in the city center of Amsterdam has been a high crime area for decades. Among the crimes were high rates of street robbery, drug trafficking, drug use, human trafficking, illegal gambling and organized crime controlling real estate and businesses in the area. To a large extent, these problems are attributed to the high concentration of what is labeled nowadays by the city administration as 'criminogenic' industries, such as (window) brothels, bars, gambling houses, 'coffee shops' (regulated cannabis-outlets), 'smart shops' (shops selling legal or semilegal drugs) and 'head shops' (shops selling drug related paraphernalia). Next to criminal activities, the high concentration of these types of businesses is also related to problems of disorder and public nuisance, such as public intoxication and violence. All these issues have a negative impact on feelings of safety and the perceived livability in the area.

In this paper, we focus on the history of the projects aimed at tackling (organized) crime and nuisance in the Red Light District. We review existing research covering three main periods in the history of crime control in the district, characterized by a shifting focus to different crime problems and different approaches. Our goal is to assess the lessons and effects of multi-agency approaches to reduce crime, uphold justice and improve safety in the Red Light District. Our research questions focus on five different aspects of crime policies:

1. Target: what were the problems these projects were supposed to tackle?

2. Political context: What was the political context in which the projects were initiated?

3. Policy-theory: What were the ideological, causal, and efficiency assumptions of the projects?

4. Organization and execution: How were these projects organized and executed?

5. Outcomes: What were the outcomes of the projects?

We review existing research, including evaluation research in which we and colleagues have been involved and that is published elsewhere in more detail (e.g., [3, 4]). In chronological order, the successive projects aimed at reducing problems of crime and unsafety in the districts are discussed. Key points in answering the research questions for every project are:

- The extent and visibility of crime problems and political attention;

- The choice of priorities and project goals and the various stakeholders' interests;

- The relations between the superstructure (organizational consortia and formal arrangements and covenants) and the substructure (shop floor collaboration);

- The vulnerability of the alliances of collaborating agencies (varying organizational interests, operating procedures, lines of responsibility, et cetera);

- The sustainability of these alliances [5].

In the following section, we will describe three periods in the history of the district: crime on the streets (1980s-1996); organized crime behind the front doors (19962007); and reconquering the Red Light District (2007-2011) by targeting the 'criminogenic' infrastructure and increasing collaboration in criminal investigation and enforcement. The final section presents the main results and conclusions. 


\section{Crime on the streets (1980s-1996)}

Target The Red Light District has been a center for prostitution for centuries. While pimping and an element of "underworld" were closely related to prostitution in the Red Light District and the area had rough edges, historical studies describe the atmosphere until the 1960s as bohemian, easygoing and sociable. The police kept a certain distance and public order was largely self-regulating. Major changes emerged after the 1960s. The sexual revolution led to commercialization of the new openness in the consumption of sexuality with a boom of brothels, sex-theaters, sex-cinemas and sex-shops in the area. Mass tourism to this 'sexual amusement park' made the Red Light District an object of economic speculation [6].

The introduction of drugs in the area produced even more radical changes. In the 1970s, the heroin trade was controlled by Chinese organized crime. Besides occasional in-group shootings, the trade had not yet become associated with other crime problems. This situation changed when a group of Surinamese dealers took over the trade at the end of the 1970s. They were operating from several bars in the 'Zeedijk', a central street in the area with lots of bars. The increase in the use of drugs attracted large crowds of users as well as all sorts of other types wanting to profit from the trade, such as street dealers, couriers, middlemen, lookouts, etc. In the 1980s, the number of heroin addicts rose to nearly 10,000 (1984) and the city was flooded by 'heroin tourists', particularly from Germany (see for a review: [7]).

The drug trade was accompanied by a rise in street crime, such as pick-pocketing, street robberies and tourists being robbed before they received the drugs they set out to buy. If they were able, bona fide entrepreneurs and tenants left the district and the street degenerated. The area turned into a no-go area where the police only entered in full force. In addition to this, the local police force was hit by a huge scandal of widespread corruption. Police officers were found to be taking bribes from shady entrepreneurs in the area to turn a blind eye to certain crimes [8].

Political context Local authorities were unable to tackle such crime problems for many years. In 1981, carrying knives in the area became prohibited, in 1983 restraining orders for notorious dealers were introduced, followed by a prohibition of crowd gathering. A reorganized and "sanitized" police unit slowly regained control of the street. However, public outrage among local inhabitants and remaining entrepreneurs regarding the general criminal atmosphere was still strong. In 1978 the inhabitants of the district appealed to the Queen to personally end the drug trade. In 1983 the same group occupied the city council chambers to demand action.

However, of all initiatives, the most influential was taken by local inhabitants and entrepreneurs. They realized that owning residential property was key to making real change in the street by setting up an economic recovery plan for the area. A number of banks and a large hotel chain saw economic potential in the redevelopment of the street. Reluctantly at first, the city administration joined the initiative, making the change project a private-public partnership [6].

Policy theory The goal of the project was to stop the degeneration of the Zeedijk-street and to improve livability. Reducing drug trafficking and street crime was not the main goal, but seen as a necessary condition to achieve this end. By buying properties from 
private owners, renovating them, and renting out the ground floor to legitimate entrepreneurs, the idea was that the negative spiral would be broken. By maintaining the upkeep of public spaces and by restoring social control among new tenants, it was anticipated that the street would be less attractive for drug dealers and drug addicts. The principle was: "clean behind the front door, clean in front of the front door." [9].

Execution and implementation In 1985, the public corporation - NV Economisch Herstel Zeedijk (Economic Recovery Zeedijk) - was founded and NV Zeedijk started buying properties. The initial low price of properties rapidly increased with the success of the project and buying property in that area became more difficult. Nevertheless, in the beginning of the project, it was difficult to attract entrepreneurs to start a business in one of the renovated buildings. As an incentive, entrepreneurs were offered attractive low starting rents. To tackle problems of nuisance and crime, the concept of 'social management' was introduced. This meant that new tenants were carefully selected and screened for integrity. Tenants had to agree to conditions: no sex-related products or services, no happy hours, no shutters for the shop-window at night and actively participating in maintaining a clean and livable street [9].

Effects Sixty percent of the properties on the Zeedijk have been bought by NV Zeedijk and given a bona fide form of exploitation. Although no academic studies have been done on the basis of which causality can be attributed to this approach, it is clear that from the beginning of the 1990s the image of the street changed radically. The street now has a variety of shops, bars and restaurants and is a popular place for a night out. Drug dealing and drug addicts have largely disappeared. Effects of displacement to other streets in the Red Light District were observed, but together with aging-out effects (of heroin addicts) it would seem drug use, street-dealing and drug-related crime are largely a thing of the past.

As a result of its success, the NV Zeedijk and its approach are an inspiration for later projects aimed at tackling crime problems in the Red Light District. This said, however, one of the conditions for making progress in street renewal was turning a blind eye to the integrity of investors and real estate owners, as long as they were willing to comply with the principles of 'social management'. For example, the director of one of the biggest coffee shop-chains and an alleged old-school underworld-boss negotiated via NV Zeedijk with the city council for more favorable conditions for their "businesses" in exchange for their agreement to sell properties which were necessary for the reconstruction plan [6:125].

\section{Organized crime behind the front doors (1996-2007)}

\section{The Wallenproject}

Target In 1996, the research group Fijnaut reported to the Parliamentary Inquiry Committee on Criminal Investigation Methods, chaired by Member of Parliament Maarten Van Traa. The Committee was set up as a reaction to a huge scandal related to dubious infiltration operations in organized crime groups (the so-called 'IRT affair') and aimed to take a wider view on both criminal investigation methods and the nature, scale and seriousness of organized crime in the Netherlands. 
The criminological research group reported that Amsterdam was regarded as a center for both national and international organized crime [10]. According to this criminological research group, the city was a major center in the world market for narcotics. In addition to groups from native and immigrant communities, many foreign groups were active in the (illegal) distribution of (illegal) goods. Some of these groups had - mainly in the inner city districts and especially in the Red Light District — built up economic positions of power in real estate, brothels, hotel and catering sector, and in prostitution. With regard to the Red Light District, the researchers concluded that criminal individuals and groups had, through their illegally acquired property and capital, gained practical control of the economic power. As a result, this enabled them de jure and de facto to decide who can develop what (illegal and/or legal) activities, and in this way determine to a high degree the level of public (dis)order in this area [7: 126]. The report stated that indecisiveness of the local authorities had created a fertile breeding ground for illegal and criminal activities in the Red Light District. The report referred - anonymously to 16 criminal organizations in particular which allegedly had become key players in this area.

Political context The findings of the Committee, which were extensively broadcasted in the media, came as a shock to Amsterdam city politics. The political debate produced an official request to the Mayor and Aldermen to draft an action plan for the prevention of organized crime, and not wait for the national policies and regulations that were to result from the Parliamentary Inquiry. The plan of action announced 77 actions to enhance the defensibility of the city administration against the threat of organized crime. This approach consisted of a number of instruments, ranging from integrity tests for civil servants, the purchase of strategically positioned buildings and the refusal or withdrawal of permits, to the screening of companies competing for major public contracts. Due to the specific problems in the Red Light District, members of the Amsterdam City Council emphasized that additional administrative attention should be devoted to this part of the city center, and instigated the appointment of what came to be known as a Red Light District manager in 1997. The Red Light District manager and his team were asked to develop a methodology for the administrative approach to organized crime [11].

Policy theory The administrative approach to organized crime formulated by the city council and further developed by the Red Light District manager was based on three causal assumptions [3]. First, and following the conclusion of the Fijnaut research group, it was assumed that real estate plays a crucial role in organized crime. Real estate transactions can be an element of money laundering schemes. Proceeds of crime can be invested in real estate. Real estate can be used for illegal purposes, such as illegal housing or producing cannabis. Owning real estate also means controlling the type of commercial exploitation of that (especially ground floor) real estate and therefore to a certain extent, the Red Light District project was aimed at getting an insight into real estate ownership and regaining control over the exploitation of property.

A second important causal assumption was the presumed relationship between low levels of 'livability' - both in a social and an economic sense - and public safety on the one hand, and organized crime on the other. It was not only assumed that organized 
crime had a negative impact on livability and safety, but inspired by the successes of the gentrification of the Zeedijk, it was also assumed that a regenerated Red Light District would be less attractive for organized crime.

Third, it was assumed that due to administrative backlashes, poor law enforcement, and lack of interest, public administration in Amsterdam had lost control over certain areas and economic branches, and had inadvertently provided ample opportunity to criminals to commit crimes and launder their money. The solutions to this problem seemed rather straightforward: more accurate information, better cooperation between the various agencies within the municipality, and better cooperation between public administration, police, and tax authorities [12].

Execution and implementation Spearheaded by the Red Light District manager and his team, the project was officially a multi-agency approach, for which the police, public prosecution service and tax authority had signed a covenant to participate and exchange information. By submerging himself in the work of street-level police and municipal officials and by joining them day and night 'on the beat' and talking to entrepreneurs, the Red Light District manager developed an extensive network in the area. The Red Light District manager and his team were asked to develop a methodology for the administrative approach to organized crime. They developed a 'seven-step-plan' which basically consists of two components: first, the collection and analysis of relevant information, and second, the taking of measures on the basis of this information. Acting on criminal intelligence together with signals the Red Light District manager had received through his network, localities and businesses considered vulnerable to organized crime were selected for investigation. Then several steps were taken to get a clear picture of the ownership and exploitation of the selected properties or businesses, linking information from public sources, municipal records, and classified information from the police, judiciary, and tax authorities. With regard to the latter, the project team was given special authority by the Minister of Justice to have access to classified police information. The idea was to collaborate these different types of information to initiate further target action for the maintenance of public order. Due to the fact that different partners cooperated in the project, a wide range of measures could be taken: the refusal or withdrawal of licenses and permits, the levying of taxes, the closure of certain establishments, the instigation of a criminal investigation, and under certain circumstances, the acquisition of real estate by the city itself, in order to prevent criminals from investing their money in specific objects [3].

Effects The most direct impact of the appointment of the Red Light District manager and his actions for the Wallenproject was the creation of a legal basis for the exchange of information in a multi-agency context and producing a toolkit for an administrative approach to tackle organized crime. The project and methodology were as yet too young to expect visible effects on the problem of organized crime in the district. Furthermore, an evaluation of the project showed a strong dependency on the Red Light District manager and his extensive personal network in the area. For this reason, it was decided to prolong the Wallenproject, as part of the wider Van Traa project [3]. 


\section{The Van Traa project}

Target In 2000, 3 years after the start of the Wallenproject, the name of the project was changed into Van Traa project (named after the chair of the Parliamentary Inquiry Committee) and its scope was extended to the city of Amsterdam as a whole. The approach developed for the Red Light District was to be used to target problems of organized crime in various vulnerable areas and sectors in the city. The application in the Red Light District was to be continued and implemented in the regular administrative procedures of city administration.

Political context On a national level, the Ministry of Justice was still busy implementing the recommendations of the Parliamentary Inquiry Committee. New laws were drafted. Combating organized crime still had a high national priority. The city of Amsterdam was seen as a front runner in developing an integrated, multi-agency approach to organized crime. Delegations from other cities, the Parliament, other countries and even the Council of Europe visited Amsterdam [13]. The Van Traa team organized excursions in the Red Light District to show this novel approach, which was already regarded as a success by the city administration.

Policy theory As in the Wallenproject, the Van Traa project assumed a relationship between low levels of livability and public safety on the one hand, and organized crime on the other. Due to this proposition, for a long time the main focus of the administrative approach to organized crime has been on deprived areas and marginalized economic sectors.

Execution and implementation In the Van Traa project the methodology developed by the Red Light District manager, was also applied to other city districts and in specific economic sectors, which on the basis of varying information and assumptions were seen as vulnerable to organized crime. While the Van Traa team was spearheading these new projects outside the Red Light District, the responsible agencies of the city center council were supposed to take over their application in the Red Light District. In 2003, the BIBOB Act came into force, making it legally possible to refuse or revoke licenses on the basis of a serious cause for concern that these would be used for criminal purposes. In addition to using its own methodology, the Van Traa team also coordinated the implementation of the BIBOB Act on behalf of the city of Amsterdam.

Effects In 2005, the results of an evaluation study of the Van Traa project were published [3]. The report observed that 56 properties had been acquired in the inner city and were given a bona fide exploitation, four illegal casinos had been put out of business, about 20 licenses for bars and restaurants had been refused or withdrawn, several bars had been temporarily closed, the ownership and financial structure of whole city blocks and economic sectors had been screened, and a structure for the regulatory enforcement in the Amsterdam harbor had been created. Last, but not least, preventative screening procedures for issuing licenses and providing subsidies had been introduced.

Due to the fact that the city administration had hardly any specific tools to fight organized crime until the BIBOB Act came into force, some of the city's interventions 
came down to calculated 'administrative harassment'. Only after the BIBOB instrument became available, could the administrative approach to organized crime become really effective. The city administration started to apply the law on the sectors of hotels, catering, prostitution, gambling establishments, and construction. An internal evaluation showed that in the first 5 years, 4,400 permits were checked, 300 files were selected for further study (180 in the center district), 80 were sent to the national BIBOB agency, which concluded that there was a serious threat in 60 cases, resulting in 30 permits being refused or revoked [14].

Without a baseline assessment of organized crime in the area fit for this purpose and due to the lack of a reliable assessment of organized crime by the police, it was impossible to determine to what extent these measures had decreased the problem of organized crime [12]. Reliable conclusions on causality require experimental research designs or statistical analyses. Since criminal entrepreneurs generally try to hide the illegal nature of their business, these methodological requirements cannot be met when evaluating the effects of measures on organized crime. Due to the difficulties of acquiring data, Levi and Maguire [15] argue that for organized crime it remains largely a matter of belief that there is some effect.

As mentioned earlier, the project assumed a relationship between low levels of livability and public safety on the one hand, and organized crime on the other. Targeting organized crime should therefore lead to a decrease in street crime. The municipal safety plan 2007-2010, however, reported that 560 high frequency offenders are active in the city center. Pick-pocketing and street robbery remain a problem in the Red Light District. According to the plan, the types of businesses in the area amass problems of disorder and crime. In the Objective Safety Index the area is qualified a 'relatively unsafe'. In the period between January 2009 and July 2010, CCTV cameras registered hundreds of crime incidents in the area. Nevertheless, since 2003, registered crime has decreased by $68 \%$ in the Red Light District [20: 104]. This might indicate a correlation between the problem of organized crime in the Red Light District and the problem of street crime, although McCord and Tewksbury [16] found that it is the presence of sexually oriented businesses which relates to increased levels of crime in a community.

One of the greatest challenges in the project was the interpretation of the collected data. Can indications of money laundering or other organized crime-related activities be inferred from an overview of property leasing and letting, together with the financing and exploitation of properties? The instrument developed did provide for the collation and analysis of data, but did not provide for the assessment of the results: no indicators have been developed to determine what degree risk exists that certain observed constructions indicate criminal activity. In practice, it was usually information from the police and judiciary concerning the person involved that was decisive in determining whether organized crime can be assumed.

Although the police and the public prosecutor's office were officially partners in the project, and the covenant created a legal basis for information exchange, relevant criminal intelligence was not always provided for two reasons: 1) on the shop-floor level of the criminal investigation units many police officers were reluctant and suspicious to share criminal intelligence with non-police partners and 2) strategic policies of the Van Traa team and police were not aligned whereby criminal investigations were not producing the kind of information that could be used for preventative purposes by the city administration. 
While ostensibly being a multi-agency effort, the actual collaboration scarcely reached the level of real joint action. With the exception of the Van Traa team, the contribution of most actors is better typified as cooperation without engagement. The existence of a specialized team dedicated to the prevention of organized crime served as an excuse for others to refrain from becoming involved. Despite the fact that in the policy plans the necessity of a multi-agency approach was stressed, the external parties seemed to take the position that they were merely assisting the public administration in preventing organized crime. The implementation of the project in the city's standard procedures did not meet expectations [12].

\section{Reconquering the Red Light District (2007-2011)}

\section{Project 1012}

Target According to a report by the Van Traa team in 2007- "Limits of law enforcement: New ambitions for the Red Light District" - the policies described above were not enough to have a serious impact on the problem of organized crime in the inner city center. The area remained attractive to organized crime and continued to offer a 'criminal infrastructure' due to the high concentration of 'criminogenic' sectors such as (legalized) brothels, (regulated) cannabis coffee shops, smart shops, gambling establishments, bars and so on. Labelling certain sectors as 'criminogenic' and suggesting substantial reductions in size, may be considered to be an important turning point in the history of a city that is widely known for its tolerant attitude regarding vices.

This conclusion was in line with the ambitions of the city administration to bring about a major and far-reaching functional transformation in the Red Light District. Their goal was to "regenerate the district into a worthy entrance area to Amsterdam as one of the world's leading cities." [20: 281] This grand plan involved nothing less than a substantial reduction in the number of buildings used for window prostitution and coffee shops, and redeveloping the bottom segment of the hotel sector by enabling legitimate investors to buy up dubious hotels. The City Council's proposals suggested that this component of the policy to achieve the envisaged functional change in the city center would require a $40 \%$ reduction in the number of window brothels, from 477 to 293 windows, and a reduction in the number of cannabis coffee shops from 76 to 50 [4].

Political context An important part in the political context of the new problem definition was played by the Deputy Mayor of Amsterdam - who is Deputy Prime Minister of the country at the moment of writing - who published a book entitled 'Envisions of the future of the inner city'. In this book, he attacked the typical tolerant Dutch attitude towards prostitution and took a radically different position: that no woman chooses this profession voluntarily and that the city should not facilitate human trafficking. Referring to Red Light District, he is very clear about his ambitions: “... rather one tourist attraction less than being accomplice to the trafficking of women." [17]. 
In the same time period, a notorious police investigation, the so-called 'Sneep' case, showed how violent pimps were still able to exploit women in the legalized prostitution sector. Prostitution was legalized in the Netherlands in 2000, but this case showed how German pimps came over to Amsterdam with some prostitutes and gradually took over a significant part of the Red Light District, using other pimps, bodyguards, and prostitutes to extend their business. It was clear that legalizing prostitution had not eradicated human trafficking, as some proponents of legalization had hoped. As particularly violent activities were demonstrated in this case, human trafficking related to prostitution rocketed to the top of the local and national political agenda (e.g., [4, 18-20]).

Policy theory In 2007, the city of Amsterdam launched a project called 'Project 1012', named after the ZIP code of the inner city of Amsterdam, including the Red Light District. The policy theory was that the high concentration of bars, coffee shops, brothels, and other drug- and sex-related venues function as a 'criminogenic infrastructure'. Since the capacity of public administration and enforcement agencies is limited, the goal of this project is to reduce the size of this criminogenic infrastructure by substantial reductions of certain sectors (attracting the wrong kind of people) and zoning. As mentioned before, the proposals referred to a $40 \%$ reduction in the number of window brothels, from 477 to 293 windows, and a reduction in the number of cannabis coffee shops from 76 to 50 . Furthermore, zoning regulations aim at concentrating prostitution in certain areas, which also means that other areas and main 'tourist arteries' become prostitution free. The main aim is to attract different types of tourists, other types of businesses, and other types of investors to the Red Light District, e.g., middle-aged and middle-class tourists visiting the historical city center for museums, shopping and fine dining instead of backpackers, bohemians and bachelors visiting bars, coffee shops or brothels.

Execution and implementation One of the main activities of Project 1012 consists of buying real estate by an alliance of banks, public housing corporations and the city administration. Some of these properties are bought from owners who know their licenses will probably be revoked (as a result of BIBOB-screening) and from owners of premises with activities that will no longer be possible in the near future due to zoning plans regarding e.g., prostitution areas. Furthermore, brothels and coffee shops are closed due to results of BIBOB-screening. All operators of brothels and coffee shops had to apply for a new license and some of them did not pass the BIBOB-test.

Particularly the zoning plans and the reduction in size of the prostitution sector and the coffee shops led to resistance by owners who have vested interests in the Red Light District. Also, operators of brothels and coffee shops who lost their license made objection to these decisions. Significantly, since whole economic sectors are subjected to preventive measures such as the BIBOB screening, mainstream entrepreneurs in these branches feel indirectly criminalized, according to research conducted by the Amsterdam Region Business Association [21]. In addition, entrepreneurs are confronted with a lot of extra paperwork and costs. This led to protests by the Amsterdam Region Business Association and representatives of the liberal party in the city council, claiming that the execution of the BIBOB Act has apparently cost the entrepreneurs of Amsterdam 1.1 million Euro and is believed to have damaged the entrepreneurial climate. 
Effects It is difficult to make an assessment of the final results of this project since the project is still running. Project 1012 is planned to take ten years. Second, some of the plans were not executed as intended. The economic crisis and some other financial setbacks forced the city of Amsterdam to reconsider their financial priorities. Buying up property is costly and some of the private parties involved in the project also had to reconsider priorities due to the economic crisis's profound effect on real estate and investment options. Moreover, due to inaccurate financial planning, the project is costing more than the city can afford and it is therefore, slowing down. ${ }^{1}$

\section{Emergo}

Target In addition to Project 1012, the city administration, Amsterdam police force, Public Prosecution Service, Tax Administration, Ministry of Finance, Home Office and the Ministry of Justice agreed to start a new, collaborative project. As was already concluded in the evaluation of the Van Traa project [3], many parties worked together to combat organized crime, but usually took the form of cooperation without engagement. This did not lead to a truly integrated approach to organized crime as it was envisioned [22]. For this reason, project 'Emergo' was launched in 2007. Emergo had two goals: first, close collaboration supported by research and analysis to gain an understanding of how criminal power is concentrated and the underlying criminal opportunity structures in the Red Light District; and second, to use the obtained information to take specific action through a combination of administrative, fiscal and criminal law enforcement, to seize every possibility to break these concentrations of power and opportunity structures, and prevent future recurrence. To a certain extent, these two goals are interrelated, since priorities in criminal investigation and enforcement shape the knowledge about criminal activities in an area. If agencies do not investigate certain activities or arrange collaborative enforcement actions, knowledge and information about criminal activities will remain limited. One type of Emergo activity focused on criminal investigation, while the other focused on combined enforcement actions [4].

Political context There was high political priority on a national level $\mathrm{f}$ or the Emergo project, since all major parties had signed the new covenant and all parties, including e.g., the Ministry of Justice, the Home Office, the city of Amsterdam, the police and the Tax Department, had a commitment to fulfill.

Furthermore, as already mentioned, the 'Sneep case' and the violent activities that were demonstrated in this case, resulted in human trafficking related to prostitution becoming a top priority on the local and national political agenda.

Policy theory The policy theory of Emergo was similar to the policy theory of Project 1012: "By limiting this criminogenic infrastructure and therefore making it less

\footnotetext{
${ }^{1}$ In 2011, only one 'window' was acquired. In March 2013, the Amsterdam newspaper Het Parool reported serious financial problems which could threaten the execution of Project 1012. Asscher stressed the difficulties of 're-conquering' the Red Light District from organized crime and that this would require 'a deep breath' (see among others, interviews with the former council member in Het Parool d.d. 29-2-2012, and Trouw d.d. 3003-2012).
} 
obscure, organized crime will have fewer opportunities and there will be more opportunities to control this crime effectively in a preventive and repressive way." [20: 292]. However, Emergo mainly focused on the ways in which criminal investigation and collaborative enforcement actions could contribute to this goal.

Execution and implementation Emergo was a 4-year project with a sizeable, albeit limited budget, but still dependent on the priorities and capacity of the collaborating agencies. Overall project control was exercised by a steering group and a project team with representatives of all involved agencies. One team was concerned with criminal investigation (the Serious Crime group), and the other with collaborative surveillance and control (the Enforcement Group). A small group of researchers assisted in analyzing problems and data. The initial phase of Emergo was time-consuming and it took considerable time for the project to gain momentum (see for more details: [20: 284285]): "One reason was the project's organizational complexity. After all, the cooperating organizations and agencies are largely autonomous, and none regarded Amsterdam's city center as a unit of territorial organization. This meant that before the project, cooperation had been the exception rather than the rule." Another problem related to the lack of a clear legal framework for exchanging information, which took about a year to accomplish. A third problem was the lack of proper, up-to-date police analyses of crime problems in this area. To a certain extent, the project had to start from scratch and could only produce more insight by stimulating criminal investigations and enforcement actions by the collaborating agencies.

Besides intelligence gathering and the exchange of subject-based information for administrative interventions, six large criminal investigations were started in areas such as money laundering, the drugs trade, and human trafficking [20: 285-296]. Particularly the collaboration in human trafficking investigations showed that increasing collaboration between the city of Amsterdam and the police had been successful [19]. A common problem for the city of Amsterdam is that criminals often use 'straw men'as a method of circumventing the license criteria since a bogus man without a criminal record may successfully apply for a license. Wiretaps by the police, however, illustrated that as soon as any problems arose - such as a letter arriving from the tax authority or the local government - the 'straw man' immediately called his real boss and discussed these problems with him. This evidence made it possible for the local government to withdraw licenses. Other evidence revealed that direct negotiations about rooms took place with pimps (rather than with prostitutes) and that a café was used as a meeting place for pimps, where they could monitor their prostitutes in the alley via the cafe's surveillance cameras. The tax authority also invested time and energy in human trafficking investigations (primarily by attending meetings), but to little effect, except for providing information about the income and property of suspects.

Effects It is difficult to assess the direct effects of the Emergo-project: "In some cases, such as trafficking in women, the link is clear. In other cases the link is less conspicuous and less direct, but no less important, such as in the action against illegal and some legal hotels, against certain coffee shops and bars, and against the massage parlors. The opportunities for serious organized crime, and for plucking the fruits of such crime, were curtailed in these ways." [20: 291]. As was the case with the Van Traa 
project, direct results of a project can sometimes be assessed, but assessing the effects on (organized) crime is very difficult.

\section{Conclusions}

In this paper, we described three periods in the history of the Red Light District as well as shifts in the definition and framing of central crime problems: crime on the streets (1980s-1996); organized crime behind the front doors (1996-2007); and reconquering the Red Light District (2007-2011).

First, four aspects of these shifts in the definition and framing of central crime problems should be noticed:

- From drug related street crime to organized crime, money laundering and sex trafficking. During the first period drugs dealing, drug addicts and related crime and nuisance were the main problems, but this shifted over the years to organized crime, money laundering and sex trafficking.

- From crime on the streets to crime behind front doors. During the first period crime and nuisance problems were visible and directly victimizing the public. This shifted to crime problems behind the front doors, which are barely visible and lead only to indirect or abstract victimization or victimization of 'others' ((immigrant) women).

- From 'criminal' to 'criminogenic'. During the first period criminal activities were clearly criminal according to the Criminal Code, but this shifted to a debate about 'criminogenic' activities that allegedly provide the breeding ground for criminal activities.

- From an instrumental discourse to a moral discourse. During the second period there was an instrumental focus on the development of administrative tools to prevent organized crime. During the last period, the discourse involved more normative arguments, particularly regarding sex trafficking and the fact that the city of Amsterdam should not be an accomplice to sex trafficking. In a traditionally 'tolerant' city, in a country that has legalized prostitution, this was quite a sudden change [23].

Second, there was also a shift in causal assumptions. During the first period, the main focus was on regulating vices in order to transform a criminal market. Particularly during the last period, regulated vices were increasingly viewed as outlets for organized crime and curtailing criminogenic industries was viewed as a possible way to curtail opportunities for organized crime.

Third, during all periods, the main problem was the absence of data and a proper threat analysis. Much was unknown about criminal activities and active criminal groups and much remained unknown, as criminal investigations rarely targeted activities and persons operating in this area in a systematic way. An exception was perhaps the 'Emergo'-project, but this project also showed how much was unknown. As a result, priorities of projects could not be based on analysis and were the result of political priorities and assumptions. 
Fourth, all three periods contain evidence on how hard it is to forge and sustain alliances between government agencies. It is quite difficult to agree to focus on a single topic by various agencies with different organizational goals. In Emergo, this problem was circumvented by aiming at different goals, e.g., human trafficking for the police and the city of Amsterdam, and the hotel sector for the Tax Department. Furthermore, it is difficult to focus on a single area such as the Red Light District, as these agencies often focus on a wider area and face competition from priorities of other areas and other policy problems. Even in Amsterdam, the Red Light District is just one area of the city, while crime problems in other areas withdraw capacity from participating agencies. Finally, projects gain momentum due to temporary political priority, but implementation often stagnates before aims are achieved and devoting capacity to these projects in the long run is a continually recurring problem.

Fifth, effects of these projects are hard to measure, except for visible street crime. Visible street crime has been strongly reduced, as is shown by crime statistics and can be experienced by walking around the district. However, it is not clear whether less visible forms of crime (money laundering, sex trafficking) have been reduced, because these phenomena are 'hidden' problems that can only be revealed if law enforcement agencies focus criminal investigation priority to these problems, creating a typical 'Catch-22-situation'. The result is often decreasing political support for the costly and radical interventions that are largely based on empirical assumptions and moral attitudes about the power of organized crime in the district.

These findings are not only relevant for the Netherlands, but also for other countries. In many modern cities, attempts to reduce crime, uphold justice, and improve safety are the result of a complex interaction between collaborating agencies and the wider social and political system. In the academic literature and in policing practice, there is an emerging focus on Third Party Policing and multi-agency approaches (e.g., [5, 24, 25]). Our findings suggest that we should take this interesting issue further by looking beyond the police as the central actor.

The challenges of multi-agency collaboration are manifold and research should focus on at least five issues. First, processes related to the political agenda, including the fact that many crime problems are hidden problems and only reach a sufficient level of credibility for the political arena after considerable efforts have been made by the criminal justice system to prove the very existence of a hidden problem (such as human trafficking in a legalized prostitution sector). Second, these processes can be studied within the wider political system, but also within the cooperating agencies themselves. Internal and external political support are equally important to study. Third, these collaborations relate to shared interests, but research should also focus upon different goals, work processes, cultures, and policy cycles of cooperating agencies. Fourth, both formal aspects of collaboration should be studied (including laws and regulations; and barriers for the exchange of information) and informal aspects (such as shop floor collaboration). Finally, we should widen the predominant instrumental focus to normative and political issues such as changing norms, priorities, and increasing and decreasing internal and external support for certain policy lines and actions. More critical research into these issues will generate new knowledge about the fragile character of these collaborations and the reasons why some collaborations succeed and others fail. 
Open Access This article is distributed under the terms of the Creative Commons Attribution 4.0 International License (http://creativecommons.org/licenses/by/4.0/), which permits unrestricted use, distribution, and reproduction in any medium, provided you give appropriate credit to the original author(s) and the source, provide a link to the Creative Commons license, and indicate if changes were made.

\section{References}

1. Kingdon, J. W. (1995). Agendas, alternatives, and public policies. New York: Longman.

2. Wilson, J. Q. (1989). Bureaucracy: what government agencies do and why they do it. New York: Basic Books.

3. Huisman, W., Huikeshoven, M., Nelen, H., van de Bunt, H., \& Struiksma, J. (2005). Het Van Traaproject: evaluatie van de bestuurlijke aanpak van georganiseerde criminaliteit in Amsterdam. Den Haag: Boom Juridische uitgevers.

4. Projectgroep Emergo. (2011). De gezamenlijke aanpak van de (zware) georganiseerde criminaliteit in het hart van Amsterdam. Amsterdam: Boom.

5. Schuilenburg, M. (2015). The Securitization of Society. Crime, risk, and social order. New York: New York University Press.

6. Van Diepen, P., \& Vlas, A. (2010). Zoden aan de Zeedijk: 25 jaar NV Zeedijk. Amsterdam: NV Zeedijk.

7. Korf, D. J., Kleemans, E. R., Decorte, T., \& Boekhout van Solinge, T. (2006). Drugs en drugshandel in Nederland en België. Tijdschrift voor Criminologie, 48(20), 115-130.

8. Fijnaut, C., \& Bovenkerk, F. (1996). Parlementaire Enquêtecommissie Opsporingsmethoden. Inzake opsporing; enquête opsporingsmethoden, Bijlage XI:deelonderzoek IV onderzoeksgroep Fijnaut: De georganiseerde criminaliteit in Nederland: Een analyse van de situatie in Amsterdam - Een analyse van de situatie in Enschede, Nijmegen en Arnhem. 24 072, nr. 20. Den Haag: Tweede Kamer 1995-1996.

9. Van Dieren, J. (2008). De unieke aanpak van de NV Zeedijk. Vitale stad, 10, 26-27.

10. Fijnaut, C. J. C. F., Bovenkerk, F., Bruinsma, G., \& Van de Bunt, H. G. (1998). Organized crime in The Netherlands. The Hague: Kluwer Law International.

11. Brants, C. (1998). The fine art of regulated tolerance: prostitution in Amsterdam. Journal of Law and Society, 25(4), 621-635.

12. Huisman, W., \& Nelen, J. M. (2007). Gotham unbound Dutch style. The administrative approach to organized crime in Amsterdam. Crime, Law and Social Change, 48(3-5), 87-103.

13. Ayling, J. (2014). "Going Dutch"? Comparing approaches to preventing organised crime in Australia and the Netherlands. European Review of Organised Crime, 1(1), 78-107.

14. Huisman, W. (2012). The application of administrative law against organized crime. Refusing and withdrawing licenses as incapacitation. In M. Malsch, M. Duker, \& H. Nijboer (Eds.), Incapacitation: trends and new perspectives (pp. 185-202). Farnham: Ashgate.

15. Levi, M., \& Maguire, M. (2004). Reducing and preventing organized crime: an evidence-based critique. Crime, Law and Social Change, 41(5), 397-469.

16. McCord, E. S., \& Tewksbury, R. (2011). Does the presence of sexually oriented businesses relate to increased levels of crime? An examination using spatial analysis. Crime \& Delinquency, 59(7), 1108-1125.

17. Asscher, L. (2005). De ontsluierde stad. Amsterdam: Uitgeverij Bert Bakker.

18. Huisman, W., \& Kleemans, E. R. (2014). The challenges of fighting sex trafficking in the legalized prostitution market of the Netherlands. Crime, Law and Social Change, 61(2), 215-228.

19. Verhoeven, M. A., Van Gestel, B., \& De Jong, D. (2011). Mensenhandel in de Amsterdamse raamprostitutie. Een onderzoek naar de aard en opsporing van mensenhandel. Den Haag: Boom Juridische Uitgevers.

20. Verhoeven, M., Van Gestel, B., De Jong, D., \& Kleemans, E. R. (2015). Relationships between suspects and victims of sex trafficking. Exploitation of prostitutes and domestic violence parallels in Dutch trafficking cases. European Journal on Criminal Policy and Research, 21(1), 49-64.

21. De Vaan, K. B. M., \& Bont, P. F. H. (2011). Integriteit beoordelen: advies over de toepassing van de wet $B I B O B$ in de gemeente Amsterdam. Amsterdam: Regioplan Beleidsonderzoek.

22. Fijnaut, C. (2010). Introduction of the New York double strategy to control organized crime in the Netherlands and the European Union. European Journal of Crime, Criminal Law and Criminal Justice, 18(1), 43-65.

23. Huisman, W., \& Nelen, J. M. (2014). The lost art of regulated tolerance? Fifteen years of regulating vices in Amsterdam. Journal of Law \& Society, 41(4), 604-626.

24. Mazerolle, L., \& Ransley, J. (2005). Third party policing. Cambridge: Cambridge University Press.

25. Mazerolle, L., Higginson, A., \& Eggins, E. (2013). Title registration for a systematic review: third party policing for reducing crime and disorder: a systematic review. The Campbell Collaboration Library of Systematic Reviews, (http:/www.campbellcollaboration.org/lib/project/291/). 